\title{
Friends, Partners \& Co: A Sustainable Model for the Media?
}

\section{Gabriela Pedranti}

\author{
SemioticaStudio / IED Barcelona, Spain
}

doi: 10.7358/ijtl-2015-001-pedr

gabriela@semioticastudio.com

\begin{abstract}
The emergence of active prosumers redefined what we used to understand in terms of media proposals. Through Eliseo Verón's concept of reading contract, Pierre Levy's idea of collective intelligence and different ideas around fan cultures (proposed by Henry Jenkins and Carlos Scolari), this paper would like to present the analysis of a case study that challenges the old concepts regarding publishing and media: Orsai, nadie en el medio. Originally a blog, Orsai became a high quality paper magazine with no advertising in 2011 and later, a publishing house. They launched new magazine in February 2014, Bonsai. The hypothesis proposes that they have understood how to establish a meaningful bond with these new audiences; it is such a strong bond that inspires loyalty beyond reason. The readers want to become part of the project, and they are willing to invest in it (both economically and emotionally). This is related to the other economies that Jenkins talks about in his recent book Spreadable Media. This research is going to reflect on an (alternative) model for media in the 21st century, based upon Orsai's experience, and also mention some other examples of flexible models, similar to this one.
\end{abstract}

Keywords: media; prosumers; models; economies; press; indy; crowdfunding.

\section{INTRODUCTION}

Many traditional print media are still struggling to fully understand how to engage the current audiences. The model that worked during the 20th century is not giving the same results nowadays in terms of readers and revenue. What is quite clear is that currently, publics want to be more involved, many of them want not only to be heard but also to be taken into account and participate.

Something that is also important to consider is that the new possibilities around sharing, transforming, communicating and exchanging ideas and 
content deeply transform the perception and traditional roles of the followers of any media or brand, in digital and physical life-which are equally real nowadays -, so readers/followers/prosumers do not only want to participate and be heard, but they also want to do it in new ways.

As Carlos Scolari said in many of his talks and texts, people are gathered around content and stories, not in front of specific media or devices any more; their media diet is tailor made, in terms of contents, timetables and devices: "new audiences are not media centered, they are narrative-centered," as he put it in his talk at Semiofest (Scolari 2013b). Traditional print media industries are not accepting this change easily, and there is still a long way to go for them.

What this paper will try to understand and explain is what can be picked up from other media that are getting this profound change quite quickly: those which we still call alternative or Indy media. Learning from their experience, this research will propose some key ideas for different media models, an area that is still and constantly being developed.

This paper analyzes a case study that is probably one of the purest experiments in the Spanish-speaking world: a print magazine with no advertising, which is a profitable business (in terms of living out of writing, editing and illustrating). The project is Orsai, nadie en el medio (Orsai, no one in the middle).

The hypothesis proposes that Orsai has understood how to establish a meaningful bond with these new audiences, and it is such a strong bond, that it inspires loyalty beyond reason, to such extent that it cannot be understood with the traditional industry models, techniques and explanations. And nevertheless, it is a valid business alternative in these times in which we gather around narratives and contents.

The apparently recent attitudes of the audiences - which have always been there, but are enormously seen, noticed and expanded since the arrival of Internet and social networks - are related to the other economies that Henry Jenkins, Sam Ford and Joshua Green talk about in their recent book Spreadable Media and the complexities these economies represent (Jenkins et al. 2013). Nothing is ever free, and not everything is related to financial compensation or money exchange.

As mentioned before, this paper would like to reflect on an alternative model for media in the $21^{\text {st }}$ century, based upon Orsai's experience, and also mention some other examples of flexible proposals, similar to this one at least in some aspect (Libero, Jot Down, elpuercoespin.com.ar, eldiario.es) and how traditional media, such as El Mundo or $A B C$ newspapers in Spain are learning - or at least, trying to - from it.

The aim is to establish the main findings from these proposals that can be organized as a first map for a useful model - and a stronger version of the reading contract (Verón 1985) - for (print) media in the $21^{\text {st }}$ century. 


\section{LITERARY REVIEW}

Some of the communication theories and concepts that appear in this paper are: the reading contract proposed by Eliseo Verón, which is defined as a bond in time between the medium and its followers (Verón 1985); the gift and value economies by Henry Jenkins, Joshua Green and Sam Ford, as proposed in their recent book Spreadable Media (Jenkins et al. 2013), which links with the idea of "collective intelligence" by Pierre Lèvy and applied by Henry Jenkins in the analysis of fan cultures he does in Convergence Culture (Jenkins 2006).

Ideas, reflections and strategies that appear in Carlos Scolari's recent talks and books such as Narrativas Transmedia (Scolari 2013a) and Lostología, estrategias para entrar y salir de la isla (Scolari et al 2010) are also used for this research.

Many other books, talks, and digital content are included, which can be found in the List of References or footnotes.

\section{Methodology}

This paper will explore the main case study mentioned before, as well as some other examples. It will do so by connecting Scolari, Verón and Jenkins' theories to them, using concepts and tools from design thinking, semiotics and communication.

It focuses on the Spanish speaking world, because this is quite a big market for any online or print publication: according to Instituto Cervantes' 2012 annual report "El español, una lengua viva" (Instituto Cervantes 2012), this language is spoken by more than 495 million people.

This paper will analyze - step by step - the evolution of the Orsai project (2004-2014), in order to understand and explain their model and proposal. It will also reflect on the mixed models the other mentioned media are working with nowadays, through examples and analyzing how they present themselves to the readers and how they keep the conversation flowing.

The conclusion will focus on proposing a map of key ideas and practices that can help to generate a flexible model for keeping the readers/followers/ prosumers interested and to develop and sustain a profitable business (in terms of living out of writing, illustrating and publishing). 


\section{THE PROMISE AND THE CONTRACT}

Based upon Emile Benveniste's theory of enunciation and with some echoes of Umberto Eco's The Role of the reader. Explorations in the semiotics of texts, Eliseo Verón reflects on the process/experience of reading to define his reading contract. He says that "linguistics has always privileged words over writing [...] an extra reason for not reflecting upon reading processes." (Verón 1985, 1) On the other hand, "In semiotics it has always been easier to work on the texts instead of asking about the way in which they are read [...] semiotics has not shown interest for the readers and even less, for those who do not read." (Verón 1985, 1) Although semiotics has evolved since then, in particular in the field of applied projects, and thanks to the contribution of British Cultural Studies, Verón's observation was quite true in 1985 . He also made a comment on sociology: "Regarding sociologists, they have accumulated information about the readers, without asking for the social functioning of texts". (Verón 1985, 2) In this panorama of disconnected knowledge about readers and texts, the concept of the reading contract is one of the first clear attempts to understand the relationship between these two parties, "which is no other than the process of reading, that social practice that until now has been invisible." (Verón 1985, 2) According to this author, the relationship between a reading device/medium and its reading process lays upon the reading contract, which connects the discourse of the medium with its readers. It is a bond that has to be taken care of, in order to go on working in the long term.

Verón observed that the success of a print medium is measured through its capacity of proposing a contract that is correctly articulated with the expectations, motivations, interests and contents of the imaginary of the readers; its ability of keeping up the evolution of its reading contract in order to follow up to its readers' socio-cultural development, always preserving the contract; and its faculty of modifying the reading contract if the situation demands it, in a coherent way. (Verón 1985, 2-3)

We can infer the reading contract and its proposal through a systematic analysis of the signs we find in the style, design, contents, etc. of the analyzed media, which work as clues to make visible all the threads connecting the readers and the medium, the view on the world they share, their values and beliefs... The author says that there are three requirements that lead the analysis of the reading contract:

- The regularity of the described features;

- The differentiation that appears when we compare different media/writing devices;

- The systematicity of the properties shown by each medium.

This concept is an interesting starting point that explains what happened with print media until the Internet became massive: different proposals talked to 
different audiences who shared a similar view on the world, that had a similar judgment about what facts had to become news and also, the tone in which these news were written. Most print media in Spanish followed the old tradition of telling the readers something they didn't know, a pedagogical model that went on at least until mid-seventies in Spain and mid-late eighties in Latin America, when most countries of the region recovered their democratic governments. El País in Spain, founded in 1976, and Página/12 in Argentina, founded in 1987, are two good examples of new reading contracts and models, that modified the traditional proposal, and started to talk about current issues from a more democratic and open point of view, and also - at least in style and tone - engaged the readers in a certain conversation.

With the arrival of the Internet, and even more with the irruption of social media, this situation has exploded: readers and consumers become active participants of what is being said, giving constant opinions about how do they see the world, and looking for much more than a magazine or newspaper letting them know what is happening. This may seem obvious if we consider our daily experience with media; nevertheless, an industry that has worked practically in the same way for over 100 years, finds it quite difficult to re-invent itself, in particular because most print media do not want to accept the world has changed, as also has the relationship with the readers. What was a profitable business, in most cases with an important social function, has to do things differently if it wants to survive in the new century. And this is exactly what Indy media - currently with far more possibilities due to the technical and social changes the Internet has produced - got right from the start.

\section{VALUE, WORTH AND GIFT: THE OTHER ECONOMIES}

Henry Jenkins, Sam Ford and Joshua Green build on the idea of a moral economy, as proposed by E.P. Thompson in 1971. He used this expression to "describe the social norms and mutual understandings that makes it possible for both parties to conduct business". (Jenkins et al. 2013, 52) One of the main ideas they point out of this theory is that all the participants have to feel everyone is behaving in a morally appropriate way. Within this frame, they try to establish some participatory processes that emerged with Web 2.0, instead of simply thinking about spreading and sharing content as piracy, which is still one of the main official views on this matter. They try to understand and explain the complexity of a new situation, where an industry claims copyright on certain stories and contents, while many active prosumers do not only spread the word about those contents, but they also share, comment and even parody/modify 
them. They observe there are some different views going around about fan labour, which ultimately leads to an increase of the sales of the companies (Is it free? Is it exploitation? Is it fair?), and some prosumers are already seeking compensation for the hours they spent working on a sort of co-creation.

The frictions, conflicts, and contestations in the negotiation of the moral economy surrounding such labor are ample evidence that audiences are often not blindly accepting the terms of Web 2.0; rather, they are increasingly asserting their own interests as they actively renegotiate the moral economy shaping future transactions. (Jenkins et al. 2013, 58)

In order to understand this complex situation, they point out it is crucial to acknowledge the diverse kinds of value that appear here, and that producers/ industries and audiences tend to follow different reasoning or logics. The prosumers who create content (in a professional or amateur way) are not just looking for remuneration; in addition, they are looking for recognition, they are trying to influence their peers and even society; also, in many cases, they are trying to express personal meaning(s). In this kind of exchanges, "status', 'prestige', 'esteem' and 'relationship building' take the place of cash remuneration as the primary drivers of cultural production and social transaction." (Jenkins et al. 2013, 61)

So if we can start picturing many economies here, meaning "different systems of appraising and allocating value" (Jenkins et al. 2013, 63), we can easily get their point: there are other powerful drivers, that are not directly related to making a financial profit, which are getting more and more entangled in our constant relationship with the media, the industry and the content producers. New times, new frameworks: it should be crystal clear, but it is quite complicated for traditional print media.

As the authors indicate, the concept of gift economy - which originally comes from anthropology - has been used several times in theories and books about the digital world. It has become a useful expression for understanding some aspects of the virtual sphere, such as the informal exchanges. Nevertheless, they observe there is a sort of crash within the functioning of Web 2.0 as we know it, because at a certain point it assumes everything has to become a commodity (in other words, it will make profit for someone), so it contradicts the intention of some people who just want to share/give content as a gift.

Following Lewis Hyde, author of The Gift (1983), they say that "a commodity has 'value' while a gift has 'worth"' (Jenkins et al. 2013, 67). Exchange value can be quantified, it is related to a rate, based upon recognized ways of determining this value; but worth is related to meaning, it has no price, and nobody can determine an agreed value for it. These are the main economies that are entangled in the complex relationships we have with media today. So 
here comes THE question: "How might we negotiate the range of possible exchanges value-to-value, worth-to-worth, value-to-worth, worth-to-value-that such a vocabulary implies?”. (Jenkins et al. 2013, 69) They make some observations that are not only useful but vital for media companies trying to keep the conversation flowing with their audiences, in order to still have a business: at some point, value has to be transformed into worth, so the proposal/ content/experience becomes priceless; the economic investment transforms itself in a sentimental/emotional one. Although it is a difficult process - "from commodity culture in which they are produced to informal social contexts through which they circulate and are appraised" (Jenkins et al. 2013, 72) -, it is absolutely essential.

The way each media company does it, it is up to them to decide; but it is really important to keep in mind that the audiences are playing a much more meaningful role than they had ever before; most of the prosumers media industries want to keep by their side in order to run their business will not take a change of skin as real commitment. Furthermore, regarding information, articles and written pieces, there is so much to choose from, so much more accessibility/affordability (even through legal access, in terms of the copyright industry, such as online libraries)... Why would the readers choose one medium over the other? That's the key point: by offering them worth, something money can't buy.

\subsection{Freebies or invisible investment?}

Through the analysis of some cases of music bands publishing their work under a Creative Commons license such as Nine Inch Nails did with their album The Slip in 2008, Jenkins, Ford and Green add a very interesting observation: while the press was shouting about the economic cost of the album and considering that the band was giving away their work, the musicians - through his font man, Trent Reznor - had a very different view on this: it was a way of thanking their followers for their support; "rather than 'giving the album away', Reznor was giving back to the fans for what they had already given him - their previous support and purchases - with an unspoken request that they continued to support him." (Jenkins et al. 2013, 73)

There is a similar example with singer and composer Amanda Palmer, and her incredibly successful Kickstarter project in 2012, which was the most supported music project on Kickstarter up to that date (also in terms of revenue: she asked for 100,000 dollars and she got almost 1.2 million). Through a direct appeal to the followers, in a straightforward way, she asked them to help her in developing her project because she didn't want to do it 
with a traditional record label. There were two phrases shown on the video that really gave hints about the reading contract/commitment she was offering and asking for: "This is the future of music" and "We are the media". (Kickstarter 2012) In addition, the rewards for helping her with a certain amount of money were those that money can't buy: limited edition of the album and book, vinyl records, signed art books and exclusive invitations to different launch parties around the world(Kickstarter 2012) In a TED talk she gave later, "The art of asking", she made an interesting point about numbers in the view of traditional industries and the new and flexible models for running her business: for the record label, selling 25,000 copies of the record were a failure because sales were going down; the same number of followers gave Amanda their trust and 1.2 million dollars. (Palmer 2013)

In this situation, nothing is ever free: continuous exchanges of effort, interest, time and many other forms of worth are constantly carried out; the main problem is that many media industries still think only in terms of money exchange, of value. If they start to understand the new possibilities of connecting with followers that spend/invest their time and emotion in spreading the word about content they love and projects they believe in, they will have a possibility of thinking beyond copyright/piracy and moving into the more fertile lands of co-creating a joint project with their audiences, that can provide a profitable business. And it is not just about talking about it: followers/readers/prosumers are attentive and they want real and tangible proof of the promises/agreement. They are not only buying but investing, and they want to choose and decide where to get the best profit (in terms of worth and some times, value).

\section{ORSAI: HACKING THE INDUSTRY RULES}

It all started as a blog. It was 2003 and a young Hernán Casciari - who had gone to Paris from his native Argentina to receive a literary prize - fell in love with a Catalan girl and he moved to Spain with her. He was feeling alone in a foreign country and that's why he started writing on a recently launched publishing platform: a blog. He thought it was a way of keeping in direct touch with his friends and family, who were an ocean apart. So by mid-2003, he started the adventure by writing short stories on a blog called Diario de una Mujer Gorda (A fat woman's diary) which later changed to the definite name it has today, ;Más respeto, que soy tu madre! (Show a little respect, I am your mother!). Here, the writer was disguised as a middle-class housewife called Mirta Bertotti, who was writing about her daily life with her eldest son's help, 
who knew about computers. The experiment had such an interesting feedback by Spanish speaking people from different parts of the world (although it was written in very local Argentinean Spanish), that Casciari decided to start writing with his own voice. As he was still a bit lost and lonely, with a feeling of not being allowed to play in his new country, he gave this new blog a meaningful name: Orsai, which is the Argentinean football jargon for off-side.

\subsection{Orsai's proposal and (business) model}

On February $27^{\text {th }}, 2004$, he started this new adventure, writing a post called "El viejo folletín y las nuevas tecnologías" (something like "The old serialized novel and the new technologies") in which he explained the previous experiment with Mirta Bertotti's blog-novel and encouraged writers and journalists to "make incursions in this genre, which possesses the big advantages of literature and editorial column, and lacks it is evident disadvantages." (Casciari 2004a)

He went on writing short texts and stories on Orsai for a long time, listening and paying attention to his followers, chatting with them through the comments, building a strong bond that is a great example of what Verón calls the reading contract, a bond in time between the addresser and the addressee; an agreement that needs attention, respect for the terms of the proposal and continuous agreement with the readers.

Due to the success of his blog, Casciari was asked to write columns for two important newspapers: La Nación, from Argentina and El País, from Spain. His short stories from the blog were also published as books by many publishing houses around the world: Plaza \& Janés (Spain), Grijalbo (Mexico) and Sudamericana (Argentina), among others.

After three years of working with the publishing industry, he thought things could be done in a different way. He was already feeling uncomfortable due to last-minute advertising that kept changing the quantity of words he had to write for the newspapers; some ideological editorial lines did not represent his own points of view; he also found out that he could not control the sales of his books in any way, although he suspected - in some cases, due to informal talks with people who owned bookstores-that he sold more books than the publishing houses told (and paid) him. But that was how the industry worked... So he had no option: accepting or quitting. And he did so: he gave up everything in September 2010. He posted his decision on his blog, giving his reasons to the readers. And also being honest with himself in an exercise of transparency with his followers: "I learnt, above all, that I can only have fun in a medium with no advertising and that I can only sleep well on Fridays - a whole night's sleep, with no interruptions-in a medium with no ideology." (Casciari 2010) 
So that was the moment in which he decided to start publishing an impossible magazine, in terms of the traditional media and publishing industries: it would be edited by himself, his best friend and his family, from his own home, in a small town in Catalonia, Spain. They would offer contents of great quality, both in writing and illustration, in a magazine with the best possible paper, with no advertising at all and long texts, to recover the pleasure of reading. In addition to this, as they believed culture should be accessible/affordable for everyone, they would offer a free $\mathrm{PDF}^{1}$ after the publication of the paper magazine, so anyone who had access to the Internet could read it. Later, he said this was a way of encouraging people to get to know the magazine, to spread the word and ultimately, to buy it; he even advised other publishing houses to do so (Casciari 2011c). He started to explain his idea through posts on the blog and the feedback was amazing: 10,000 people pre-bought the magazine without really knowing what it was going to be about (Casciari 2011b). Moreover, the readers became the distributors: they could buy the magazines in packs of ten copies, so they would be able to sell and distribute the magazines in their area, something that extended the availability of the publication (and later, books) to some places in which the traditional publishing houses would not care to sell some editions because it was not profitable. Something deeper than the traditional reading contract was growing there: a joint, associative project that would offer quality contents to anyone who could read Spanish. During the first and second years, distributors could choose if they wanted to make a profit or not. Many of them didn't.

Three years later, the impossible idea proved to be an alternative work and business model: Orsai magazine published 16 issues until December 2013 (the second issue was immediately sold out), and also versions for tablets ${ }^{2}$; Orsai publishing house was born in late 2011(they have launched around 10 books up to date) ${ }^{3}$; they had a pizzeria in Sant Celoni, Barcelona, Spain, in 2011'4 a bar in Buenos Aires, Argentina until 2013, where they held many kinds of cultural activities, writing courses ${ }^{5}$ and served home made pizza ${ }^{6}$ - currently,

1 All the magazines are still available at http://editorialorsai.com/revista/. Last access March 17, 2014.

2 Orsai Pad site can be accessed here: http://orsaipad.com/. Last access March 17, 2014.

3 The first contract they signed with an author and their view on the matter can be checked here: http://editorialorsai.com/blog/post/adios_industria_editorial; the books from "Colección Embudo" can be seen here http://editorialorsai.com/blog/post/proyecto_embudo and Casciari's own books, here: http://editorialorsai.com/blog/secciones/?cat=2. Last access March 17, 2014.

4 Some information about this pizzeria can be found here: http://editorialorsai.com/blog/post/ las_pizzas_de_comequechu. Last access March 17, 2014.

5 The information about the last edition of the writing courses (called Masters of Orsai University) and its students can be checked here: http://editorialorsai.com/masters/. Last access March 17, 2014.

6 The Facebook profile of the bar is still online here: https://es-es.facebook.com/OrsaiBar. Last access March 17, 2014.

International Journal of Transmedia Literacy - 1.1 - December 2015

http://www.ledonline.it/transmedialiteracy/ 
it has evolved to Orsai $\mathrm{Club}^{7}$, a sort of bookshop that offers private dinners. And in February 2014, a new magazine was born: Bonsai, a publication to be read by the whole family, edited by a fictional character and his crew: a father who is a widower, his three children, his cheeky brother and his father, a Basque immigrant in Argentina who always wears a poncho to look local and says he is a fortune teller (he was a former character of Casciari's writings). The first issue (4.000 copies) was completely sold to the distributors in packs of ten magazines, with a discount, so they can make some profit from it (OrsaiBonsai 2014).

\subsection{What Orsai understood}

When he started telling his community of readers about the Orsai project, Casciari made an effort of being honest in order to reconnect with his followers. He knew the key to the upcoming magazine was there. As he said in a TEDx talk, he knew later than he had made a mistake some years before: "I think I made a rather serious mistake. I went to work with the industry, I ended the direct communication with my readers, and I let them put intermediaries [...] All these people lined up between me and my readers." (Casciari 2011b)

Whether working with the traditional industry or not, this is a key finding for media in the $21^{\text {st }}$ century: listening and talking with the readers/followers/ prosumers. Direct connection, feeling the pulse of the audience and being attentive/answering to their reaction is essential to keep them by your side. Nowadays, the reading contract is not only changing, it is being put under close examination by a great number of people.

What he noticed and assumed at the end of 2010 was that his whole contract with the readers was not only based upon writing good content, but also in talking, listening and having a real conversation with them, as he had been doing for so many years on the blog. Moreover, this was not just a question of tone or style: he had built this community of readers - without asking them to become so - because of this attitude of sharing, learning, being part of the same project: it was not just what he said or how he said it, but also the fact of building a community of interests in which the participants shared worth, according to Jenkins, Ford and Green's definition (Jenkins et al. 2013). Orsai blog was originally a space for Spanish speakers around the world who did not only feel identified with the writer's views, but who felt they could share their concerns, ideas or thoughts, and were going to be heard and respected. The roles of enunciator and enunciatee, as proposed by Benveniste, were

7 Some of the experiences can be checked here: http://editorialorsai.com/club/post/primera_cena. Last access March 17, 2014.

International Journal of Transmedia Literacy - 1.1 - December 2015

http://www.ledonline.it/transmedialiteracy/ 
completely and constantly exchangeable, between the author and the readers, but also among the readers themselves. Many of the most interesting conversations took place (and still do) in the comments section. And this gave them something more, something that could not be estimated in terms of money exchange, and also offered what could not be achieved by one individual: collective intelligence in action. Pierre Lèvy developed the ideas of collective intelligence and collective knowledge, in order to establish through sharing and gathering knowledge, ideas and experiences, this union of people can produce learning that is not possible to get separately.

The knowledge of a thinking community is no longer a shared knowledge for it is now impossible for a single human being, or even a group of people, to master all knowledge, all skills. It is fundamentally collective knowledge, impossible to gather together into a single creature. (Lèvy 1997, 20)

What happened with the first reactions to the Orsai project confirmed what Casciari knew, and also went much further: as mentioned, people from around the world started buying the magazine massively, without knowing about its contents, on a pre-sale. What happened here can be seen as a twist in the relationship of print media with their readers: Orsai moved from the reading contract to an agreement based on trust. And it was not just an Indy magazine, that you could find in your neighbourhood by chance: taking good advantage of new media and technologies, but also letting the conversation flow, Orsai was also a business, that allowed their creators to make a living out of it.

If the reading contract was still a proposal from the medium - although the readers had to accept it -, the trust agreement is based upon a much more democratic principle: we talk, we exchange ideas and at a certain point, and by mutual compromise, we decide we can trust each other. Moreover, this agreement has to be shown, seen and talked about; it has to express itself in real actions and attitudes (and not only in a book of style of a multimedia company, that in many cases worked just as a bunch of good intentions that were not taken into real action).

Orsai kept the agreement transparent and simple: they talked to readers, letting them know about the actions and ideas for the development of the magazine and the rest of the project. They did it in a very casual tone, close to the readers, and showing clearly they cared about their followers' views. What is also very important is that they asked the readers to become an active part of the project: by distributing magazine and books, suggesting ideas, even writing in the publication and of course, reading. The traditional idea of doing business with print media is completely changed here: an editor of a magazine with no advertising, listening constantly to the readers, talking with them, and also giving them a free digital version of the magazine for those ones who could not 
afford it. This can be summed up in a sentence from Amanda Palmer's TED conference: "I think people have been obsessed with the wrong question, which is, 'How do we make people pay for music?' What if we started asking, 'How do we let people pay for music?"”. (Palmer 2013) If the followers feel and see that they are investors, the lift from value to worth and worth to value (back and forward, really) easily comes by: we know what this is about, we participate, big advertisers are not deciding on the content, we have enjoyed this space and its contents, we want it to go on, so we are willing to put our effort, enthusiasm and money into it. Some of the best examples (among many others) that show this commitment in Orsai are: the Pri game (which started as soon as the comments were allowed in 2004/2005, and is a personal contest among the readers: the one who writes the first comment has to write Pri: the first three letters of primero (the first one in Spanish) ${ }^{8}$. This is such a meaningful experience for both author and readers that when the blog turned 10 years old in 2014, Casciari recognized this spontaneous and unspoken contest by setting the rules and giving rewards according to what he calls The secret Pri game: "The Pri game is about adding up points through making initial comments in the blog posts of a fat man, who does not know about the existence of the game and believes his readers are anxiously waiting for his stories". (Casciari 2014b) Another representative example of the comradeship Orsai has with its audience is the post that invited everyone in the world who was an Orsai reader or a follower to organize a global picnic for the launch of the second issue, in order to celebrate they were part of a different and enjoyable project. The headline of the post reinforces the promise and the agreement in the long term: "This time, we trust you". (Casciari 2011b) Plenty of illustrative examples are found throughout the blog: it is always talking in a tone and about subjects that include the reader; it is a never ending "inclusive us" as Benveniste called it. (Benveniste 2004)

One of the most important steps in term of commitment and giving proof of understanding the publishing business in a different way was the post "The end of piracy", when Casciari offered the readers the free PDF version of the first issue:

This is the most expensive text in Orsai. And the one I was really willing to publish [...] This PDF was not uploaded anonymously in Rapidshare, it not in the secrecy of the Internet. Every writer and artist got paid for his work. And now, the work is free. By this simple act, we close the matter of piracy on the Internet." (Casciari 2011c)

By keeping this promise in the long term and also giving proof of this attitude, through diverse actions and facts (for example, some of his books are also

8 A quick explanation of the game can be found here (comments 78 and 79): http://editorialorsai. com/blog/post/kodama_en_orsai. Last access March 17, 2014. 
available for free in issuu ${ }^{9}$ ), Casciari and Orsai showed that is was a different project, that really believed some things could be done differently. As the author put it:

I also had the objective of showing, and showing to myself, that the famous industry crisis that everyone is talking about it's not a financial crisis: it's a moral one, it's a greedy crisis [...] One night, with Chiri, my best friend, we wrote a decalogue, a sort of promise to the readers: $[\ldots]$ we promised that the magazine would neither have advertising $[\ldots]$ nor any private or public subsidy. We promise it would have the best graphic quality available in the market, $[\ldots]$ that it will avoid as many middlemen as possible, $[\ldots]$ and that it would have a free PDF version, so it could be read, even if people could not pay for it. (Casciari 2011c)

Another way of showing this was the contract they wrote for Horacio Altuna, the first author who published a book with them. Casciari and his best friend decided to give the author the online tools to check his sales, among many other benefits; the most important of all was possibly the royalties the author would be getting for his work: $50 \%$ of the sales, something that was far away from the traditional 7 to $10 \%$ of the traditional industry. The headline of the post in which he announced all this to the readers made its point: "Goodbye, publishing industry". (Casciari 2011a)

Regarding direct participation/inclusion of the followers, the students of the writing courses (that are called Masters of the Orsai University) have their own online space on Orsai $\operatorname{blog}^{10}$ with a link to their own sites. Some other actions under the same spirit were: the distributors were invited to write short recommendations in a couple of magazines, which they did enthusiastically ${ }^{11}$; the letters to the director section was a great space for letting readers write about almost anything they considered interesting; there was an open contest on the blog in order to decide which kind of paper should be the remaining magazines published on the website ${ }^{12}$. They kept on establishing networks, physically and virtually.

9 They can be accessed here: http://issuu.com/hernan_casciari. Last access March 17, 2014.

10 It can be checked here: http://editorialorsai.com/masters/1er_cuatrimestre/. Last access March $17,2014$.

11 The section was called "Picadito" (which means a pick up game or a kick-about in Argentinian football jargon) and it was published in Orsai 11 (140/141) and 12 (142/143). Both issues can be checked online here: http://issuu.com/revista_orsai. Last access March 17, 2014.

12 This was announced in the blog and in Orsai magazine no.12, 138, under the headline "The role of the readers". It can be checked on the online version, here: http://issuu.com/revista_orsai/docs/orsai_n12. Last access March 17, 2014.

International Journal of Transmedia Literacy - 1.1 - December 2015

http://www.ledonline.it/transmedialiteracy/ 


\subsection{Readers, clients, followers and the rest}

Some of the findings Orsai put into practice are related to another key aspect in the current media landscape: the idea of a reader being a direct client does not necessarily work like this anymore; nowadays, there can be followers who love the concept of the publication and spread the word about it, even if they do not buy or read it; some people who are initially attracted by some of the other proposals, and not directly by the magazine; others who try to apply the model to their own work and ask for advice... And a successful project has to take good care of them all. Building a strong trust agreement trough different spaces and (social) media is vital to listen, integrate and answer to them all.

In relation to this, Carlos Scolari recently mentioned an important change in what Umberto Eco called the construction of possible worlds in Lector in Fabula: Eco talked about that process as an individual one - because the experience of reading and understanding was mostly individual back then (at least at the first moment) -; nowadays, that process is collective (Scolari 2013b), and not only for fiction. So, what about the skills and interests of the current prosumers that are much more than readers? How can many traditional print media still think of them as individuals who pay for and read a magazine or newspaper just looking for information, when prosumers constantly find it, exchange it, produce something more than the original piece and give their opinion on it online? Telling them that a journalist is a professional and a blogger will not do the trick; it is simply an assessment based upon the legal/ illegal or piracy/not piracy pairings, which are not enough anymore. Understanding the new media landscape and the multiple roles of whom we used to call readers, is something the traditional print media are still finding difficult, although it is essential for their survival.

Every written media (print or online) needs a new proposal nowadays: a flexible model that understands their prosumers in their daily situation, gives them added value (respecting what it means for each medium's trust agreement) and engages them in the long term due to a number of factors, that is not anymore just good content based upon the rules of the reading contract.

Through a deep understanding of the current media landscape, the situation and expectations of the readers/prosumers/followers, Orsai got many things right: they developed a flexible model that is not based upon advertising (which fell an 18\% in 2012 and has not stopped falling since 2008 according to Arcemedia ${ }^{13}$ ). It also goes beyond a sole product. Although the idea of expanding the Orsai universe can seem similar to what many multimedia did

13 Arcemedia, Control and Analysis for advertising efficiency. URL: http://www.arcemedia.es/noticia_informe_view.aspx?id=251. Last access March 17, 2014. 
when they expanded the business, there is a key difference: all the projects have the same spirit, which builds a strong trust agreement that is kept in the long run, and it can be modified without so much trouble because readers/followers are not only informed about it (in terms of transparency and honesty) but also kept updated about a project they feel as theirs, because they believe in it and they invest in it (both in terms of worth and value).

\section{OTHER CASES, OTHER VOICES}

There are many other projects that started with a flexible model, that is not only based upon traditional advertising and sales, but combining these previous paradigms with other patterns. The most successful ones are those that try to build the trust agreement with their readers, based upon transparency, high content quality and not presenting themselves as the sole owners of the medium, but including the followers/readers/prosumers in a joint project. Some of the media mentioned here are also working together, in terms of offering special editions or combinations (publications+books+diaries, etc.) from the different companies. In one case, this has evolved to a new project, FIVE MAGAZINE, a meta-magazine that "gathers five of the small publications that are starting to be noticed among the big media" (Jot Down Magazine 2013). Its first two issues include editions of: Yorokobu, Politicon, Diario Kafka, Naukas, Jot Down Magazine, Alternativas económicas, Periodismo Humano, Materia and Frontera $D$. Moreover, on March 30 ${ }^{\text {th }}, 2014$, many of these emerging (!) publications are going to publish together an issue of a symbol of resistance in Spanish journalism: El Heraldo de Madrid, one of the most important newspapers during the Second Spanish Republic ${ }^{14}$.

A quick review of six other examples will be added here - both from the traditional industry and alternative models -, in order to see that running a successful media project in the $21^{\text {st }}$ century is not just a question of money.

\section{1. eldiario.es (Spain). Becoming a partner}

Under a very appealing tagline, Periodismo a pesar de todo (Journalism in spite of everything), eldiario.es was launched in September 2012, under a Creative

14 Jot Down Magazine. 2014. URL: http://www.jotdown.es/2014/03/convocatoria-unica-del-heraldo-de-madrid/. Last access March 21, 2014. 
Commons BY-SA 3.0 license ${ }^{15}$. It is an informative online newspaper (its name, literally, means the daily newspaper), managed by

a group of journalists who still want to keep trying. We are motivated by the ambition of buying our own freedom, supporting and defending our profession, owning the newsroom we work at and guaranteeing therefore that our editorial line is independent and does not answer to hidden interests. (eldiario.es 2014)

Their business model is based upon a mixed system: advertising and subscription, but with a new view on the role of the reader: they become partners. This is the word the use to ask for contribution, instead of talking about subscribers.

Something that works in terms of reinforcing the trust agreement of eldiario.es is what most readers already know (and is clearly written in the FAQ section):

eldiario.es is a groups of journalists who come from different media which are in crisis or were closed. We know there are colleagues that are unfortunately sharing this situation. We want to create alliances with those with whom we share social and professional principles. That's why eldiario.es has cooperation agreements with journalists in different autonomous communities such as Catalonia, Galicia or Valencia. (el diario.es 2014)

They reinforce the idea of partnership with the readers by explaining what they do with the money, because they recognize transparency as one of their main values (something that is deeply related to the original social function of journalism, and seems lost in just doing business today...) They publish it on the web and also send this information to their partners. They also talk about their meetings, objectives and ideas for the upcoming months.

This works well because we have already moved from the idea of objectiveness to fairness. Most $21^{\text {st }}$ century readers/prosumers understand and know that informative journalism always gives a point of view, representing reality in a certain way. Those media which pretend to be telling the sole and only truth are unconvincing nowadays. So the active readers who want to be informed and recognize the value of fair journalism, want to become a part of the project. Every text has a final line: "This article is possible thanks to your contribution. Become a partner." (eldiario.es 2014)

They have issued 4 numbers of Cuadernos, a magazine in paper that is free for the partners/subscribers and can be bought in bookshops and newsagents for 5 euros. There is also a Kindle version. The current cost of being a partner is 5 euros per month. According to OJD, they had more than 7 million visits in February, 2014 (OJD interactiva 2014). Only 3\% of their readers were

15 Creative commons. 2014. URL: http://creativecommons.org/licenses/. Last Access: March 21, 2014. 
partners in 2013; nevertheless, after a little more than two years, they were quite close to turn into a completely self-sustained publication (Escolar 2013). In line with the idea of cooperation among media, Hernán Casciari is currently writing on eldiario.es. He is doing what he did long ago for El Pais: writing about TV series, in a linked blog named Espoiler ${ }^{16}$.

\subsection{Jot Down, contemporary culture mag (Spain). Calling things by their name}

This is an online publication that started in 2011, when a group of friends decided to launch the magazine they would love to read. With their minimal structure and a Wordpress template, this contemporary culture mag issued a high quality paper version with no advertising in June 2012, because they thought (and their readers too) there were some articles and material that should be published in paper. As they said in a recent interview: "Our intention is to keep free access to the web content. As we were telling you before, our business model, paradoxically, relies on paper." (Flores 2013) Their editorial section on the online version shows their principles:

We believe it's possible to analyze serious things through humour, to deal with culture and leisure from another perspective and talk with their protagonists in a different way. Being able to say what we think, and not what we are told to think; entertaining without being superficial, informing without falling into an impersonal coldness, and of course, talking about sex! The 21st century is and will be the era of cultural chaos: quantity is replacing quality and the dictation of the news agencies replaces the cultivation of your own judgment. Jot Down magazine wants to run away from all this and call things by their name. There is a method in our craziness. (Jot Down Magazine 2014b)

They have some ads on the online version, all from brands or initiatives that fit their style and interests. For example, in March 2014 they have a banner from Camper shoes and a side button of Intermón Oxfam (Jot Down Magazine 2014a). For the print version, they work with the Soidem system, that allows to print on demand and also to issue a certain quantity of magazines, based upon a previous estimation. It also reduces the paperwork and gives the distributors the possibility of controlling the stock and sales online. (Soidem 2014)

They have chosen social media to keep the conversation flowing: they are very active on Twitter, keeping the style, contents and tone the magazine has.

16 Eldiario.es. 2014. URL: http://www.eldiario.es/redaccion/Casciari-viene-eldiarioes-hablar-series_6_224037616.html. Last access: March 21, 2014. 
They also answer to followers quickly and in a friendly way. They always greet their followers in the morning and at night with nice photographs in black and white, which is a feature of the magazine in every format. The Facebook profile has the same style and content, and followers comment every post. They also have an interesting Flickr profile, in which they share many photos from the articles and interviews, and from different issues they care about. They offer music lists on Spotify and SoundCloud to listen while reading some of their articles.

They publish books and some very particular stationary, which makes their special offers more tempting for the readers. After offering packs that included some other alternative magazines (such as Yorokobu, Presencia Humana, Mongolia, Alternativas Económicas, among others), they took part in the launch of FIVE MAGAZINE, as mentioned before.

For 2014, they are offering a subscription system and also a membership card which includes many benefits. One of them is having access to Filmin, an online video club that offers auteur cinema (Jot Down Magazine 2013b), among others. Their business also expanded beyond books and magazines: they also sell some home-made liquors from Galicia, something that fits the spirit of the magazine, in concept, design and quality.

Here, the concept of decentralizing the business model flows quite naturally: building networks with similarly-spirited magazines, publishing houses and even enjoyable products makes sense for the readers: they all enjoy and participate in the Jot Down (expanded) universe.

They are doing well: according to the distribution data they publish on their web, and which is audited by OJD, the official organ in Spain for this, every edition of the print version has published 15,000 copies. Out of 6 issues, the first two are sold out and some copies of the reaming four are still available. Their online version (also audited) gets 798,617 visits per month, and they have 106K followers on Twitter, and 68K on Facebook. (Jot Down Magazine 2013a)

\subsection{El Puercoespin (Argentina). Journalism with a twist}

With a similar motivation to that of eldiario.es, journalists and writers Gabriel Pasquini and Graciela Mochofsky launched this online informative magazine on March 24th, 2010 . The date is a statement itself: on March 24 ${ }^{\text {th }}, 1976$ the last coup d'etat took place in Argentina, and that date is remembered nowadays as the the Day of Remembrance for Truth and Justice. El puercoespin (literally, the porcupine) defines itself in the About section as "an online magazine about politics, journalism and culture [...] which publishes those big stories in which an anthropologist or a historian of the future would be able to find some clues about our era”. (El puercoespin 2014) 
They started with their own savings and after a while, due to the fact that what began as an experiment had 120,000 monthly visits from the world ${ }^{17}$, they decided to ask for help and turn to their own crowfunding/subscriber system, under a very appealing name: "Yo apoyo" ("I support"). In order to connect with the followers and potential suscribers, many well known writers and cultural agents from Argentina, Spain, Mexico, USA and other countries recorded videos saying why they were supporting the project ${ }^{18}$. They launched the campaign in September 2013, letting the readers know through their site, social media and a long and clear letter on their site ${ }^{19}$ what were the main reasons for this change in their model. "Think about it: for the price of a cinema ticket in your area, you will become the owner of a medium that only answers to its community" ${ }^{20}$. They offer a Club for the subscribers, with special benefits, based upon the interests of the community: an exclusive high quality magazine, free access to e books, online seminars and conferences, special discounts and the possibility of commenting the posts on the website. Here they make an interesting comment: "There are two reasons for this: because we want to abolish the era of the anonymous comments [...] and because we want that those who are committed with el puercoespin, its community, become more and more not only the ones who are reading it but the ones who are making it ${ }^{21}$." They also explain their policy for the readers who are not subscribers, who will be able to read the free content of the magazine and participate through their Facebook profile.

They do not have advertising, and there is a section of similar sites from Latin America that is called "Aliados" ("Allies"). Some of them are El Faro from El Salvador, La silla vacía from Colombia, news agency Pública from Brazil, Animal Político from Mexico, among others.

Although this seems a more traditional approach than the other cases mentioned here, it is quite a new view for informative media in Argentina, still divided in big groups and highly influenced by political interests ${ }^{22}$. El puer-

17 Pasquini, Gabriel. 2013. "El futuro del puercoespin está en sus manos". URL: http://www.elpuercoespin.com.ar/2013/09/30/el-futuro-del-puercoespin-esta-en-sus-manos-por-gabriel-pasquini/. Last access March 17, 2014.

18 Most of the videos can be accessed through El puercoespín YouTube channel. URL: https:// www.youtube.com/channel/UCis0cFB0P9Hc0zG1unSsi3A. Las access: March 21, 2014.

19 Pasquini, Gabriel. 2013. "El futuro del puercoespin está en sus manos". URL: http://www.elpuercoespin.com.ar/2013/09/30/el-futuro-del-puercoespin-esta-en-sus-manos-por-gabriel-pasquini/. Last access March 17, 2014.

20 El Puercoespín. 2013. "Porqué y cómo susbcribirse". URL: http://www.elpuercoespin.com.ar/ yoapoyo/. Last access March 17, 2014.

${ }^{21}$ Ibid.

22 A quick panorama of the current situation of mass media in Argentina can be checked here: Konrad- Adenauer-Stiftung Foundation. 2014. URL: https://www.kas.de/argentinien/es/publications/34926/

International Journal of Transmedia Literacy - 1.1 - December 2015

http://www.ledonline.it/transmedialiteracy/ 
coespin is still being published, and supported by a group of followers who want to listen to other voices in the current complex informative panorama.

\subsection{Líbero magazine (Spain). More than football}

A seasonal magazine that uses the excuse of football to talk about many things related to nostalgia, culture, stories and style, Libero was launched in the Summer of 2012. It is published under a Creative Commons BY-NC-ND 3.0 license and it has a paper version and a tablet one. It has some traditional advertising on the print version (not on the one for mobile devices), which allows this high quality paper publication to be sold for 5 euros. The approach they have is similar to some of the other publications mentioned here:

\section{Football without shouts}

Líbero is an independent project, it is not related to big publishing houses. It's a project designed by a group of journalists that one day had a dream: a football magazine that talks about the passion for this sport, without shouting, with good taste and in depth. (Revista Líbero 2014b)

They have always had a certain complicity relationship with their readers: one of the subscriptions they offer includes a table football doll, wearing the T shirt of your team (it's customizable). The name of the subscription - although it is the name of the company producing the dolls - is highly meaningful: "Alegría" (Happiness). In order to increase this relationship, in December 2012 they launched a video campaign (4 spots) under the concept of "If they explain it to you with football examples, you get it" ("Si te lo explican con fútbol, lo entiendes" ${ }^{23}$. These videos illustrate the spirit of the publication in a friendly and funny manner: football is the excuse to talk about many other interesting subjects.

Moreover, many of Libero's contents can be read online, for free, at eldiario.es ${ }^{24}$, and you can download a free preview of their first magazine (23 pages) in mobile devices. They also have an interesting blog, with full online access. There is also a special offer with Libros del KO, a small publishing house, which is sold on Jot Down Magazine online store ${ }^{25}$ (here too, the comradeship exists among the readers and many similar projects, as mentioned before).

\footnotetext{
Last access March 17, 2014. A 2011 report on media ownership can be checked here: Argentina Indymedia. 2014. URL: http://argentina.indymedia.org/news/2011/07/786889.php. Last access March 17, 2014.

23 Revista Líbero. 2013. "Si te lo explican con fútbol, lo entiendes." URL: http://www.revistalibero. com/siteloexplicanconfutbol/. Last access March 21, 2014.

24 Eldiario.es. 2014. URL: http://www.eldiario.es/libero/. Last access March 21, 2014.

25 Jot Down Magazine. 2014. URL: http://www.jotdown.es/store/\#!/ /product/id=25462282. Last access March 21, 2014.
}

International Journal of Transmedia Literacy - 1.1 - December 2015

http://www.ledonline.it/transmedialiteracy/ 


\subsection{ABC (Spain) - Are you in?}

One of Spain's most traditional newspapers, both due to its right-wing ideological line and in terms of age (it was founded in 1903), $A B C$ is trying new ways of connecting with the readers. Although its readership is quite faithful, they have noticed times are changing and something different is needed. In answer to this, they have recently launched a campaign that shows that some of the ideas of alternative media are not as wrong as the traditional industry would like to believe they are: in March, 2014, they lunched a new proposal under the concept (and hashtag) \#estasinvitado (you are invited) ${ }^{26}$. The images displayed in the campaign (their journalists smiling, showing themselves in a close way, in their daily activities) shows that even big and traditional newspapers sense that something is happening and it has to be approached in a different way: sales will not go up if you go on offering your newspaper in traditional ways; readers/ followers/prosumers want to be able to choose and to be addressed in such a way that they feel they are part of the project. Sharing a similar point of view is not enough nowadays. The text of the campaign is written in a very appealing tone:

At $\mathrm{ABC}$ we inform, we give opinions, we discover stories and lives that are worth being told. We produce real journalism, with authentic people. Like you. Brave people, who are committed, upright, rigorous... but also close, funny, optimistic. People - columnists -, such as Carlos Herrera, Ignacio Camacho or David Gistau, who everyday give us their point of view as a gift, on those issues that worry us, as well as they make us enjoy their own writing style. People - journalists -, such as Bieto Rubido, Luis Ventoso, Mayte Alcaraz or Montesrrat Lluis, who help us to organize and sort the news and to take maximum advantage of time and life. People - special columnists with their own signature -, like Beatriz Cortázar, Rosa Belmonte, Emilia Landaluce or Hughes, who discover the most uninhibited and lustrous aspects of current reality, while they draw a smile on our faces. People like you. People who connect with you, who share your concerns, who feel and dream just like you do. People who live at your side. ${ }^{27}$

They go on offering a 1 month free trial of their online proposal: "We invite you to know and enjoy $A B C$ contents in the most modern format, through our online publication on Kiosco y Más" ${ }^{28}$.

What is quite interesting here is that a business model that has been going on for longer than a century, based on the pedagogical model of telling the readers what had happened, and what's their (shared) view on it, is trying to get closer to the readership, at least in its form. Nevertheless, there are many questions that arise when the change is driven due to financial reasons, instead

26 ABC. 2014. “\#Estasinvitado.” URL: http://estasinvitado.abc.es/. Last access March 21, 2014.

27 Ibid.

28 Ibid. 
if being a core element of the proposal: Will the content answer to these new intentions? Moreover, will the $21^{\text {st }}$ century readers connect with it in new ways? Talking about the "most modern" format does not show there is a deep understanding of what is a stake: it is not a question of formats, not even of just content: it is about a whole new relationship with the followers, which can lead to more sustainable business models, that are not based upon traditional mass markets or advertising as it main way of earning money. You have to count on your readers, but with a different model, new ideas and commitment.

According to OJD, the sales they obtained in the last controlled period (July 2012/June 2013) keep on going down if we compare them to the previous year. The number of sold copies has descended to 153,645 in the last period; quite a loss if we consider its sales two years before (July 2011/June 2012), when $A B C$ sold 190,749 copies $^{29}$.

\subsection{El Mundo (Spain). (Just) A change of skin}

Another right-wing newspaper from Spain, El Mundo has been under a lot of changes lately. By the end of January, 2014, Pedro J. Ramirez (founder and News Director of the publication for 25 years) was fired ${ }^{30}$. Official reasons talk about re-thinking the project, financial problems, etc., but the general feeling in society is that is related to the political-corruption case called "The Bárcenas papers" ${ }^{31}$, which affects the ruling political party.

Nevertheless, in terms of analyzing their strategies to attract readers, there was a big one during the former news director's time: under the concept of " $E l$ Mundo changes its skin" ${ }^{32}$, they launched a video to talk about the good news: "In the sea of social media, information many times disappears to become false rumours, lies or hoaxes ${ }^{33}$. All fake news." The video goes on saying that not everything is valid, that one has to know how to choose in the big Internet noise.

They show that many other newspapers from the world, such as The New York Times or Le Monde did what El Mundo is doing: they changed their design for digital devices and offer exclusive content that has to be paid for.

29 OJD, información y control de publicaciones. 2014. URL: http://www.introl.es/buscador/. Last access March 21, 2014.

30 Publico.es. 2014. URL: http://www.publico.es/498772/pedro-j-ramirez-deja-la-direccion-de-elmundo. Last access March 21, 2014.

31 Elmundo.es. 2014. URL: http://www.elmundo.es/t/ca/caso-barcenas.html. Last access March 21, 2014.

32 Antena3.com. 2013. "El mundo cambia de piel". URL: http://www.antena3.com/videos-online/ noticias/sociedad/mundo-cambia-piel_2013110500164.html. Last access March 21, 2014.

33 Here, the video gives visual examples of social media with fake news, such as Justin Bieber being gay or the death of Fidel Castro.

International Journal of Transmedia Literacy - 1.1 - December 2015

http://www.ledonline.it/transmedialiteracy/ 
They also say that the only way of guaranteeing the survival of good journalism is giving contents a value range. And of course, they reinforce the idea that only the main newspapers of the world are credible and the reference in journalism (versus social media and similar Internet contents).

Once again, we can see a certain lift in form and not in the core idea of the model: a newspaper is shown as the voice of the final truth, and it is clearly placed against the social media production of those who El Mundo is trying to attract, which is quite contradictory. Again, a patch on an old way of doing things, based on the former relationship newspapers had with the readership: an authorized word saying what is true and what is a lie; we know, you don't. This is not a very promising proposal for what should lead to a joint project.

There is another aspect - under the current News Director, Casimiro García-Abadillo - that also shows this newspaper thinks the changes are just a question of skin and looks, and is not understanding the new rules. They insist on charging Google for using their contents for free. Maybe the problem is not their idea of reaching a certain agreement with Google, but the way they put it:

[...] We are losing money because people ask for information for free. It's about reaching an agreement with these search-engines, so they can pay for the contents they are using but that are produced by us, through a number of journalists who get their salaries every month, whom we wouldn't be able to pay in case the company went bankrupt due to financial loss. Now it seems as if everything should be free, but if so, how can journalists be paid? If Google assumes that it is going to pay all the journalists' salaries, perfect then. ${ }^{34}$

According to the mentioned concepts of worth and value (Jenkins et al. 2013), the whole new proposal from El Mundo is completely designed in terms of value. Not a single hint of worth when all they talk about is money and looks. The data from ODJ is not encouraging: from the 233,101 copies they sold in the period July 2012/June 2012 to the 187,517 they sold between July 2012/June 2013 ${ }^{35}$.

\section{CONCLUSION: NOTES FOR BUILDING A SUSTAINABLE MODEL}

As stated in the Introduction, this paper's aim was to observe and analyze the way in which Orsai understood how to establish a meaningful bond with the

34 233grados.com.2014. "Casimiro García-Abadillo: 'Pedro Jota y yo somos muy distintos. Yo soy más tranquilo”. URL: http://233grados.lainformacion.com/blog/2014/03/casimiro-garc\%C3\%ADa-abadillopedro-jota-y-yo-somos-muy-distintos-yo-soy-m\%C3\%A1s-tranquilo.html. Last access March 21, 2014.

35 OJD, información y control de publicaciones. 2014. URL: http://www.introl.es/buscador/. Last access March 21, 2014.

International Journal of Transmedia Literacy - 1.1 - December 2015

http://www.ledonline.it/transmedialiteracy/ 
new audiences, which inspires loyalty beyond reason and cannot be understood with the traditional industry models and explanations. Through the analysis of Orsai and also some observations about other media that are either proposing flexible models or trying to understand how publications work these days, we can infer that there is not a crisis in terms of interest in reading; we read (a lot), in many different ways. It is simply a crisis of the traditional industry, the $20^{\text {th }}$ century way of doing things in this area. Whether they like it or not, publications and companies have to make the effort of understanding the new scenario and be creative in finding new and flexible ways of being attractive, meaningful and valuable for readers. Moreover, they have to propose a clear joint project, in order to - using the terms from Spreadable Media (Jenkins et al. 2013) - turn value into worth at some point of their proposal.

How they choose to do it, it is up to them to decide; still, there are some interesting aspects that have worked in Orsai and the rest of media mentioned here. As a (first) conclusion, this paper would like to propose a starting point, a sort of map of a few important features that should be considered when launching and maintaining a publication nowadays. It is a starting point because communication reality changes so fast that we cannot look for absolute answers or formulas anymore. That feeling of safety is gone forever. Nonetheless, there are some attitudes that will help any project to work in the current media landscape: it's key to keep an open mind about these processes, in order to adapt them constantly to the demands of the prosumers/partners, without betraying the trust agreement. In the digital era, it is essential to establish a powerful bond that keeps people choosing and following your project everyday, whatever medium or format it is offered in. We are not just facing some changes in techniques or means; we are facing a new way of understanding communication and a revolution in the ways people can participate in an ongoing discussion about what is meaningful for them and what is not. And this will lead them to invest (or not) in different projects. (Figure 1)

So, any print/written medium that wishes to develop its own sustainable model in the current media landscape should consider the following:

- Mass media and massive sales are longer gone; the goal is reaching meaningful and faithful niche markets from around the world;

- Thinking in terms of binary oppositions (legal/illegal; payment/piracy; professional/unprofessional) is no longer useful; the idea is to move towards a deep and flexible understanding of the complex communicative reality;

- The reader is not necessarily a client anymore; instead, there are readers/fan/ prosumers who spread the word and relate to the project in different ways;

- An advertising-based model is not enough; media should work in the constant creation of different projects related to the publication and ways of financing them (crowdfunding, books, events, physical spaces, etc.); 
- The company and the clients do not operate separately anymore; the aim is to generate flexible joint projects among them;

- The reading contract should evolve to a trust agreement;

- It is not only about value; media have to provide, generate, accept and share worth.

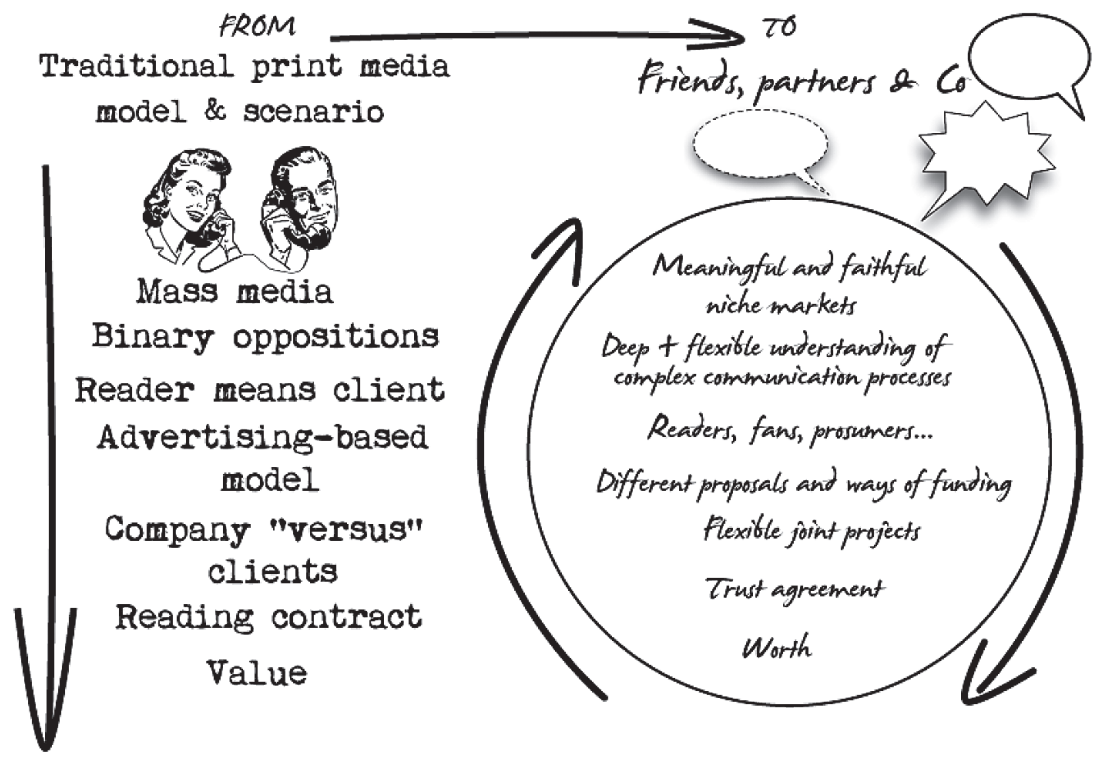

Figure 1 - Source: Own elaboration based upon research and conclusion.

\section{REFERENCES}

Benveniste, Émile. 2004. Problemas de lingüística general I. $23^{\text {rd }}$ edition. Mexico and Buenos Aires: Siglo Veintiuno Editores.

Casciari, Hernán. 2004a. "El viejo folletín y las nuevas tecnologías." Orsai (blog). February 24, 2004. Last access February 24, 2014. URL: http://editorialorsai.com/ blog/post/el_viejo_folletin_y_las_nuevas_tecnologias.

Casciari, Hernán. 2004b. ¡Más respeto, que soy tu madre! 200 chapters blog-novel. Published between September 2003 and July 2004. Last access February 25, 2014. URL: http://mujergorda.bitacoras.com/ 
Casciari, Hernán. 2010. “Renuncio.” Orsai (blog). September 30, 2010. Last access February 25, 2014. http://editorialorsai.com/blog/post/renuncio

Casciari, Hernán. 2011a. “Adiós industria editoral”. June 2 2011. Last access March 24, 2014. URL: http://editorialorsai.com/blog/post/adios_industria_editorial

Casciari, Hernán. 2011b. “Ahora confiamos nosotros”. January 62011. Last access March 17, 2014. URL: http://editorialorsai.com/blog/post/ahora_confiamos_nosotros

Casciari, Hernán. 2011c. “Cómo matar al intermediario.” Filmed November 2011. TEDx Río de la Plata video, 18:18. Last access February 24, 2014. http://www. tedxriodelaplata.org/videos/c\%C3\%B3mo-matar-al-intermediario

Casciari, Hernán. 2011d. “El fin de la piratería”. January 17 2011. Last access March 17, 2014. URL: http://editorialorsai.com/blog/post/el_fin_de_la_pirateria

Casciari, Hernán. 2014a. Orsai. Hernán Casciari’s website. Last access February 25, 2014. http://editorialorsai.com/

Eco, Umberto. 1993. Lector in fabula. La cooperación inerpretativa en el texto narrativo. $3^{\text {rd }}$ edition. Barcelona: Lumen.

Eldiario.es. 2014. Online newspaper. Last access March 16, 2014. URL: http://www. eldiario.es/

El puercoespin. 2014. Online magazine. Last access March 17, 2012. URL: http:// www.elpuercoespin.com.ar/

Escolar, Ignacio. "Las cuentas de eldiario.es." Eldiario.es online newspaper. March 5, 2013. Last access March 24, 2014. URL: http://www.eldiario.es/escolar/ cuentas-eldiarioes_6_107849233.html

Flores, Jose María. Ecoteuve.es. “Jot Down: 'Sabemos que somos raros””. June 3, 2013. Last access March 16, 2014. URL: http://ecoteuve.eleconomista.es/blogs/ periodismo-sin-bolsillos/?p=36

González, Horacio, 1992. La realidad satírica: doce hipótesis sobre Página 12. Buenos Aires: Paradiso Ediciones.

Instituto Cervantes. 2012. “El español, una lengua viva.” Last access February 6, 2014. URL: http://cvc.cervantes.es/lengua/anuario/anuario_12/i_cervantes/p01.htm.

Jenkins, Henry. 2006. Convergence Culture. Where old and new media collide. New York and London: New York University Press.

Jenkins, Henry, Sam Ford, and Joshua Green. 2013. Spreadable media. Creating value and meaning in a networked culture. New York and London: New York University Press.

Jot Down Magazine website. 2014a. Last access February 25, 2014. URL: http://www. jotdown.es/

Jot Down Magazine, 2014b. “Acerca de Jot Down.” Last access March 15, 2014. URL: http://www.jotdown.es/acerca-de-jot-down/

Jot Down Magazine, 2014c. “Suscripción ALEXANDER (Nº7 AL 12) + Filmin.” Last Access March 15, 2014. URL: http://www.jotdown.es/store/\#!/ /product/ category $=2470191 \& \mathrm{id}=30712315$ 
Jot Down Magazine, 2013a. “Datos estadísticos”. Last access March 17, 2014. URL: http://www.jotdown.es/comercial/

Jot Down Magazine, 2013b. "Megapack FIVE1 + FIVE2 + Pack Reporter." Last Access March 15, 2014. URL: http://www.jotdown.es/store/\#!/ /product/category $=2470174 \&$ id $=32906983$

Lèvy, Pierre, 1997. Collective Intelligence: Mankind's Energing World in Cyberspace. Cambridge, Massachusets: Perseus Books.

Kickstarter. “Amanda Palmer: The new RECORD, ART BOOK and TOUR.” Last access June 1, 2012. URL: https://www.kickstarter.com/projects/amandapalmer/ amanda-palmer-the-new-record-art-book-and-tour

OJD interactiva. “Evolución audiencia el diario.es.” Last access March 15, 2014. URL: http://www.ojdinteractiva.es/medios-digitales/eldiario-evolucion-audiencia/ totales/anual/3896/trafico-global/

OrsaiBonsai.com. Bonsai's magazine website. Last access:March 17, 2014. URL: http://orsaibonsai.com/

Palmer, Amanda, 2013. "The art of asking." TED video, 13:47, posted March 2013. Last access February 10, 2014. URL: http://new.ted.com/talks/ amanda_palmer_the_art_of_asking

Revista Líbero. 2014a. Magazine website. Last access March 21, 2014. URL: http:// revistalibero.com/.

Revista Líbero. 2014b. "Nosotros”. Last access March 21, 2014. URL: http://revistalibero.com/nosotros.html.

Scolari, Carlos. 2013a. Narrativas transmedia. Cuando todos los medios cuentan. Barcelona: Deusto.

Scolari, Carlos. 2013b. “Transmedia Storytelling: the semiotic challenge.” Posted August 27, 2013. YouTube video, 1:16. Last access February 2, 2014. URL: http://www.youtube.com/watch?v=NzqLIPn0440.

Soidem, 2014. “Modelos Soidem.” Last access March 16, 2014. URL: http://www. soidem.es/modelo-soidem/

Verón, Eliseo. 1985. "El análisis del 'Contrato de Lectura', un nuevo método para los estudios de posicionamiento de los soportes de los media.” In "Les Medias: Experiences, recherches actuelles, aplications". Paris: IREP.

Wikipedia. "El País.” Last access February 22, 2014. URL: http://es.wikipedia.org/ wiki/El_Pa\%C3\%ADs

Wikipedia. "Página 12.” Last access February 24, 2014. URL: http://es.wikipedia.org/ wiki/P\%C3\%A1gina/12. 